\title{
Media Development in Health Communication Studies for Health Promotion Using Technology
}

\author{
$1^{\text {st }}$ Abdul Hafiz ${ }^{1}, 2^{\text {nd }}$ Deden Mauli Darajat ${ }^{1}, 3^{\text {rd }}$ Andi M Faisal Bakti ${ }^{1}, 4^{\text {th }}$ Dewi Khairani $^{2}$ \\ \{abdul.hafiz18@uinjkt.ac.id¹,deden.mauli17@mhs.uinjkt.ac.id ${ }^{1}$, andifaisal@uinjkt.ac.id ${ }^{2}$ \} \\ UIN Syarif Hidayatullah, Islamic Studies Department ${ }^{1}$, UIN Syarif Hidayatullah, Informatics, Jakarta, \\ Indonesia $^{2}$
}

\begin{abstract}
Multimedia and health communication utilizing Internet innovations is growing the range and adaptability of mediation and showing alternatives accessible in the health sciences. Favorable circumstances of intelligent wellbeing correspondence incorporate the improved comfort, oddity, and intrigue of multimedia in computer mediated interceded correspondence; its adaptability and intuitiveness; and computerized handling. We plot a portion of these basic parts of PC intervened communication as it applies to preventive and drug. Further, various key pathways of data innovation development are making new open doors for the conveyance of expert training in preventive prescription and other wellbeing spaces, just as for conveying mechanized, self-instructional health conduct change programs through the Internet. We quickly depict a few of these key developmental pathways. We portray a few models from work we have done in Indonesia. These show how we have innovatively reacted to the difficulties of these new "data situations," and how they might be sought after in the training of preventive drug and other social insurance specialists and in the improvement and conveyance of wellbeing conduct change programs through multimedia and the Internet.
\end{abstract}

Keywords: Multimedia, Health Communication, Health Promotion

\section{Introduction}

Health Promotion Media is an effort to improve the community through learning from, by, for, and with the community, so that they can independently help themselves, and develop activities that are appropriate to the social community and support the health-minded community. (Indonesian Ministry of Health, 2007). The purpose of health promotion is divided into three levels, according to (Ahmad, 2014), which is based on the program, education and behavior.

The program objectives (long term) include reflection of the social and epidemiological phases which contain things to be achieved in a certain period related to health status. Educational objectives (secondary extension) are learning that must be agreed upon so that the education needed to overcome health problems can be achieved (Green in Ahmad, 2014). Meanwhile, behavioral goals (short term) are portrayals that will overcome health problems related to knowledge, attitudes and actions. 


\section{Health Promotion Media}

The We In conducting health promotion, it is important to pay attention to the media used in order to attract the attention of the target in attending health promotion. According to (Kholid, A., 2014) learning media are physical means to deliver learning content or materials such as books, films, videos and so on. Media is a tool used by educators in delivering educational or teaching material (Maulana, H. D., 2007).

The purpose of the use of media in teaching is to clarify the message, overcome the limitations of space, time energy, sense power, generate enthusiasm for learning, direct interaction between students and learning resources, and enable participants to learn independently according to talent (Simamora, 2009).

Media in the form of teaching aids function for (Maulana, H. D., 2007):

a. Generate target interest

b. Achieve more goals

c. Help overcome obstacles in understanding

d. Stimulate the target to forward the message to others

e. Facilitate the delivery of information

f. Facilitate the receipt of information by the target

g. Simplify the way people deliver and receive information.

h. Encourage the desire to know, explore, and get a better understanding.

i. Help enforce the knowledge received so that it can be stored longer in memory.

Implementation of health promotion requires media that can facilitate health promotion activities, especially when educators (sources) cannot meet directly with the target. The types of learning media according to (Kholid, A., 2014), namely:

1. Visual media such as graphics, diagrams, charts, charts, posters, cartoons and comics

2. Auditive media such as radio, tape recorders, language laboratories, and the like

3. Projected still media such as slides, over head projectors, in focus and the like

4. Projected motion media such as films, television, video, computers and the like.

Meanwhile, according to Sharon, S. E. (2005) discusses six basic types of learning media, thas is:

1. Text, that is: delivery of information consisting of writing.

2. Audio media, such as background noise, music, or sound recordings that can increase the attractiveness of the target.

3. Visual media, that is media that provide visual stimuli such as pictures / photographs, sketches, diagrams, charts, graphs, cartoon posters and bulletin boards.

4. Motion projection media, such as liberal films, bracelet films, TV programs, video recordings (CD, VCD, or DVD).

5. Artificial / miniature objects, such as three-dimensional objects that can be touched and touched by the recipient of the message.

6. Humans, which can consist of teachers, students, or experts / experts in certain fields / material.

The characteristics of learning media according to (Gerlach \& Ely, 1971), that is:

1. Fixative features

2. Manipulative characteristics

3. Distributive characteristics 
The criteria that must be considered in choosing learning media according to (Kholid, A., 2014) are:

1. In accordance with the objectives or competency standards to be achieved.

2. Appropriate to support the content of lessons that are facts, concepts, principles and generalizations

3. Practical, flexible and enduring

4. Pay attention to grouping goals.

5. The presenter is skilled in using media.

\subsection{Health Promotion Strategy: Advocacy \\ 2.1.1 Advocacy}

Basically health promotion aims to introduce health to the community, to achieve this there needs to be a persuasive approach, and to use communicative and innovative ways that pay attention to the target of health promotion that aims to increase public awareness about health (Maulana, 2007). Advocacy is a strategy with a leadership approach with the aim of developing health-oriented public policies (Efendi \& Makhfudli, 2009). Advocacy plays a role in supporting health promotion activities that can facilitate behavioral and environmental adaptation to improve health. Health advocates are people who care about health efforts and see the need for partners to support these efforts (Maulana, 2007).

\subsubsection{Advocacy Phase}

The commitment obtained from the advocacy process certainly did not proceed quickly because it passed through several stages. First, knowing or being aware of a problem. Second, interested in helping to overcome the problem. Third, care about problem solving (by finding alternative solutions to problems). Fourth, agree to solve the problem by choosing how. Fifth, decide on a follow-up to the agreement. Advocacy materials also need to be prepared in advance and mature, among them is according to the interests and objectives of advocacy, includes the formulation of problems and alternative solutions to problems, includes the role of targets in problem solving, based on facts and evidence (evidence-based), packaged in an interesting and clear, and according to the available time (MOH, 2011).

\subsubsection{Advocacy Approach Process}

The process of approach in health advocacy is a persuasive, mature, and wise approach. According to UNFPA and BKKBN (2002) there are five main approaches namely, involving leaders, working with mass media, building partnerships, mobilizing the masses, and building capacity (Maulana, 2007). Advocacy will be more effective if carried out with the principle of partnership, by forming advocacy networks or cooperation forums. This can support the advocacy process because there will be a process of cooperation in which there is a division of tasks and mutual support, so the target of advocacy can be directed to achieve the goals. Therefore, advocacy methods and media need to be determined carefully, so that good cooperation can be established (MOH, 2011). 


\subsubsection{Expected results}

The expected outcome using this strategy is in the form of policies and regulations that support to influence the creation of clean and healthy living behaviors and sources of support from other aspects.

\subsection{Health Promotion Strategy: Social Support and Enpowerment}

The learning process will be carried out well if the client experiences changes in the level of knowledge, awareness and behavior.

The strategies discussed usually include teaching and learning, problem solving, therapeutic use of self, care, stress management, modification of actors, making contracts, group processes and principles of nursing practice. There are three strategies that can be done to make these changes to clients, namely empirical-rational change, normative-reeducative, and powercoercive (Allender, Rector, \& Warner, 2014). In addition, according to WHO (1994) and the Indonesian Ministry of Health (2007) there are several strategies in health promotion, that is:

\subsubsection{Community Development (Social Support).}

This strategy is carried out to seek social support through community leaders, both formal and informal community leaders. The main purpose of this activity is community leaders, which can be a bridge between the health sector as a health program implementer and the community as a recipient of a health program.

\subsubsection{Empowerment is an activity}

That involves the community in the form of activities from, by, and for the community in recognizing their own health problems and being willing to maintain, improve, and protect their respective health (Efendi \& Makhfudli, 2009). The general objective in this community empowerment movement is that the community is able to recognize, maintain, protect and improve the quality of their health, including when they are sick, they can get health services without experiencing difficulties especially in costs. Targets and actors in the community empowerment movement are aimed at the direct community as the primary target.

The principle in this community empowerment movement is in the form of developing the potential of the community, fostering community contributions in health efforts, developing activities that involve inter-community togetherness, community cooperation, promotion of education and training with the utilization of local potential, efforts made in partnership with various parties and in accordance with local circumstances or culture.

In addition to the principles in the community empowerment movement, there are also forms of the community empowerment movement, that is community leaders, community organizations, community funds, community materials, community knowledge, community technology, and community decision making.

In the community empowerment movement the role of the health service in the city and district is needed in the form of assessment in helping to understand health problems in the region, giving directions related to the goals and objectives of the activities to be carried out, providing guidance and technical assistance in accordance with needs and providing moral support, provide human resource support and monitor the development of health problems 
experienced. Indicators of success towards the community empowerment movement strategy consist of input indicators, process indicators and output indicators (Maulana, 2009).

Concepts according to McGuire (1964):

Communication can change health attitudes and behaviors directly on the same causal basis. Input (stimulus) output (response to the stimulus).

Changes in knowledge and attitudes are pre-conditions in changing health behavior Input:

1. Source

2. Messages

3. Channel (channel)

4. Audience (target)

The purpose of the message delivered Output:

1. Cognitive (knowledge)

2. Attitude

3. Decision making

4. Observable behavior

Tables. Here are the things that need to be studied in the community before providing health promotion according to E.T. Anderson and J. McFarlane (2007) in Kozier, B., Erb., A.J. \& Snyder (2015):

Table 1. The things that need to be studied in the community.

\begin{tabular}{|l|l|}
\hline \multicolumn{1}{|c|}{ Things being studied } & \multicolumn{1}{c|}{ Information } \\
\hline Physical environment & $\begin{array}{l}\text { Considering natural boundaries and overcrowding, population, } \\
\text { and crime events }\end{array}$ \\
\hline Education & $\begin{array}{l}\text { Consider educational facilities both in terms of quality and } \\
\text { quantity }\end{array}$ \\
\hline Safety and transportation & $\begin{array}{l}\text { Consider security services such as the police, consider water } \\
\text { sanitation and water sources, air quality, garbage disposal } \\
\text { services, and the availability and safety of public transportation } \\
\text { and the availability of ambulances. }\end{array}$ \\
\hline Health and social services & $\begin{array}{l}\text { Consider the available health services, the number of illnesses } \\
\text { caused by various diseases, the number of deaths, the number } \\
\text { of pregnant women, infants and toddlers, coverage of health } \\
\text { efforts, and the number of health cadres }\end{array}$ \\
\hline Communication & $\begin{array}{l}\text { Consider the communication tools and media used, such as } \\
\text { local newspapers, radio, TV, internet access, public forums, or } \\
\text { informal bulletin boards }\end{array}$ \\
\hline Economics & $\begin{array}{l}\text { Consider the percentage of people who work and or attend } \\
\text { school, income levels, occupational health programs, and } \\
\text { industries that are available }\end{array}$ \\
\hline Recreation & Consider recreational facilities in the community \\
\hline
\end{tabular}

Kozier, B., Erb., A.J. \& Snyder (2015). 


\subsection{The Health Action Model}

Figures. The health action model (Tones and Tilford, 2004) identifies the major mental, social, and ecological determi-nants of people's wellbeing or disease related activities. It involves two key areas: first, the framework that adds to social expectation, and furthermore, the components that dissuade mine the probability that conduct goal will be trans-lated into training (Figure 1).

Social expectations are represented by a perplexing cooperation of convictions, inspirations, and regulating influences together with a progressively comprehensive however independently identifiable develop depicted as oneself, which has generally been portrayed as 'character.' Beliefs are intellectual and seen as likelihood decisions - for instance, the degree to which people acknowledge that smoking causes malignancy or potential activists think about that they are equipped for joining a walk to challenge poor lodging. The motiva-tion framework, then again, is full of feeling; it has to do with sentiments, feelings, demeanors, and qualities. There is association between conduct aim and inspiration. For example, individuals who accept that the tobacco business hosts influenced a political gathering may feel shock, and shock may lead them to specifically concentrate on proof that the tobacco business takes part in pay off. (Tones, K., Green, J., 2004)

The significance of social weight on conduct expectation has been all around perceived. There is additionally a connection among cognizance and influence in this unique circumstance. People's goal to act might be influenced when they (1) accept that a strategy will bring about objection from other individuals and (2) have a solid fascination in the standardizing source, and are hence inspired to agree to it. There may, obviously, additionally be connection between any or the majority of the above influences and the worldwide idea of character. For example, a 'sensation-chasing' character characteristic might be related with specific convictions and inspiration that influence wellbeing activities. (Maurice B Mittelmark, 2017)

As can be seen from (Figure 1), it is valuable to recognize three circumstances which settle on the sound decision the simple decision, in a manner of speaking. The least complex of these includes the arrangement of knowl-edge. In numerous cases individuals might be very anxious to receive a solid game-plan yet just need learning of what to do, where to go, etc. A wellbeing advertiser just needs suitable relational abilities to accomplish an effective result in such cases. Or maybe more difficult is the circumstance where specific aptitudes might be required. These might incorporate (1) psychomotor abilities, for example, fitness in legitimate utilization of a condom, (2) social association aptitudes, for example, the capacity to act confidently, and (3) self-administrative aptitudes, for example, stopping smoking. Nonetheless, the ecological framework as identified in has the best significance for people's conduct; this is taken up in the accompanying area.(Tones, K., Green, J., 2004) 


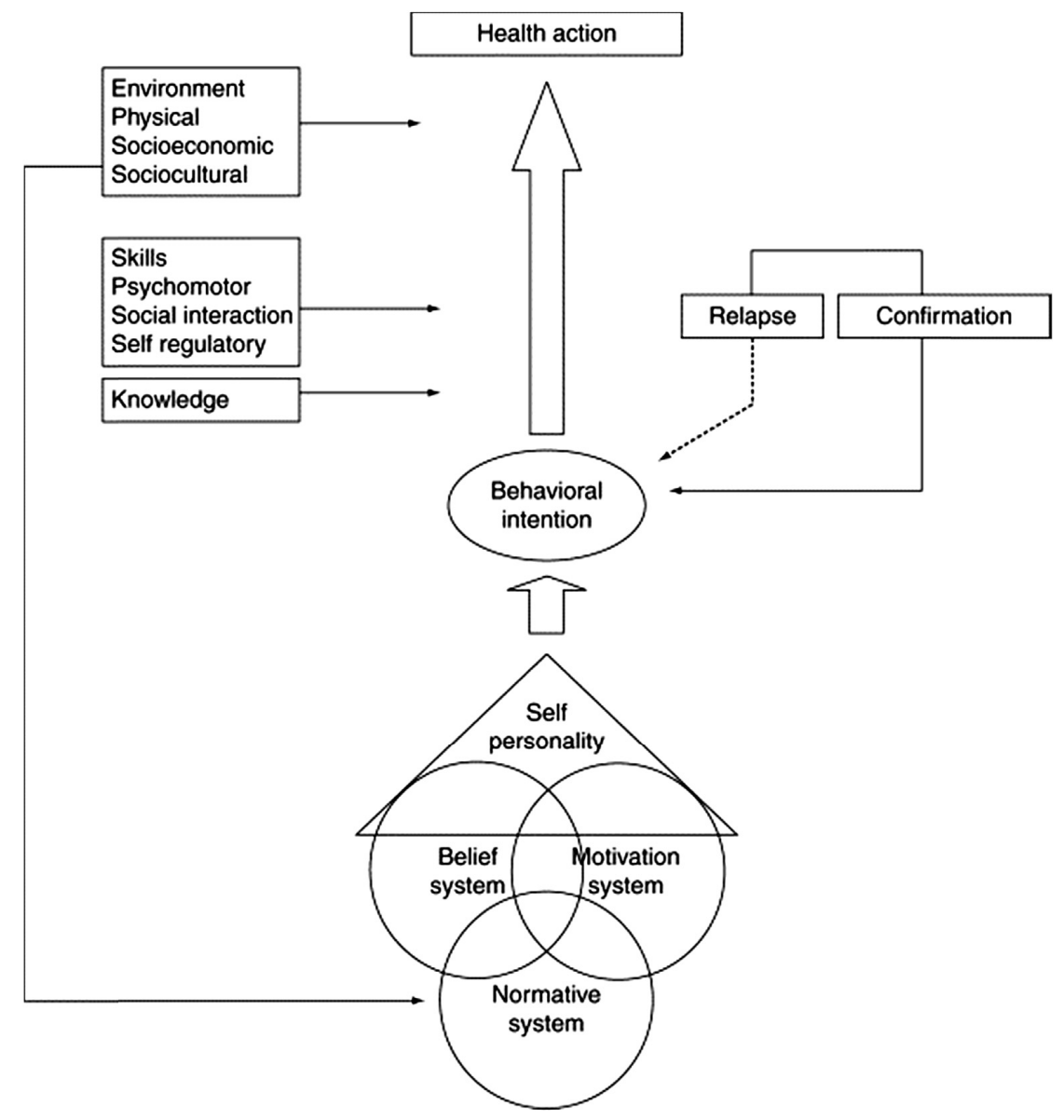

Fig.1. Health Action Model

Employments of Media to Promote Health and Public Health Interventions to Mediate the Negative Impacts of Media Positive, Pro-Social Media The Convention on the Rights of the Child calls upon states to find a way to guarantee youngsters' entitlement to life, survival, and improvement and perceives the significant job of the broad communications in such manner. In spite of the potential dangers of the media, there is a colossal measure of media delivered particularly for kids with instructive substance or expert social purpose. A few, similar to Sesame Street (a star social kids' instruction program went for preschoolers), have been created all through the world. In Palestine, Sesame Street managed resilience; in South Africa, a HIV-positive character was presented. There have been various examinations demonstrating the beneficial outcomes in various regions of Sesame Street on youngsters who watch it contrasted with the individuals who don't. Concentrates show improved psychological aptitudes, especially education and number abilities, and improved ace social conduct, for example, unselfishness, collaboration, discretion, and decrease of generalizations (Fisch, 2005). 
Battles have utilized all types of media - radio, TV, leaflets, publications, boards, intelligent media, etc - to advance wellbeing. Assessments of numerous such mediations show sway, especially when they are a piece of staggered anticipation projects like the Social Service Health Program and the University of Islamic State University Syarif Hidayatullah Jakarta and Mass Media health, which demonstrate that thorough endeavors that join media, training based, and network based exercises can delay or avert smoking in $20-40 \%$ of young people. (Goldstein and Usdin, 2016)

The contextual investigation of Soul Buddyz (see dialog underneath) gives additional proof of the certifiable constructive outcomes that a professional online life program can have. The constructive outcomes of genius web based life for youngsters are multifold: Children can turn out to be better educated and are demonstrated to be progressively prepared for school regarding math preparation, jargon, and pre-perusing status. (Goldstein and Usdin, 2016)

Ongoing examinations have additionally demonstrated that playing computer games can give a setting where members can talk about situations and results. Instructive computer games have been appeared to improve perusing and spelling. Further advantages of computer game playing incorporate empowering kids to create methodologies, test them, and adjust them (with quick input).

Some computer games energize coordinated effort, and this improves social abilities. Computer games have likewise been adequately utilized in agony the board by giving intellectual diversion to youngsters during chemotherapy for malignant growth treatment and for treatment of sickle cell ailment (Griffiths, 2005). They have been utilized as a type of nonintrusive treatment or word related treatment, for instance, for arm wounds and for expanding hand quality.

Computer games have additionally been utilized in complete projects to help create social and spatial capacity aptitudes in kids with extreme learning handicaps and chemical imbalance. (Goldstein \& Usdin, 2016)

\subsection{Conclusions}

Conclusions. Employments of Media to Promote Health and Public Health Interventions to Mediate the Negative Impacts of Media Positive. The significance of social weight on conduct expectation has been all around perceived. There is additionally a connection among cognizance and influence in this unique circumstance. The Rights of the Child calls upon states to Pro-Social Media The Convention on find a way to guarantee youngsters entitlement to life, survival, and advancement and perceives the significant job of the broad communications in such manner. Regardless of the potential perils of the media, there is a colossal measure of media delivered particularly for kids with instructive substance or star social expectation. A few, similar to Sesame Street (a star social youngsters' training project went for preschoolers), have been created all through the world. In Israel/Palestine, Sesame Street managed resilience; in South Africa, a HIV-positive character was presented. There have been various investigations demonstrating the constructive outcomes in various zones of Sesame Street on kids who watch it contrasted with the individuals who don't. Concentrates show improved subjective abilities, especially proficiency and number aptitudes, and improved genius social conduct, for example, philanthropy, collaboration, discretion, and decrease of generalizations. 
Acknowledgements. This research supported by The Graduate School of Islamic Studies UIN Syarif Hidayatullah.

\section{References}

[1] Ahmad, Kholid. (2014). Health promotion. Jakarta: Raja Grafindo.

[2] Maulana, H. D. (2009). Health Promotion. Jakarta: EGC Medical Book Publisher.

[3] Simamora, R. H. (2009). Educational textbooks in nursing. Jakarta: EGC.

[4] Sharon, S. E., James, D. R., Robert, H., \& Michael, M. (2005). Instructional Technology and Media for Learning. New Jersey: Merrill Prentice Hall.

[5] Kozier, B., Erb., A.J. \& Snyder (2015). Continuous ambulatory peritoneal dialysis: Nurses' experiences of teaching patients. Brief Communication, Saudi Journal.

[6] Tones, K., Green, J., 2004. Health Promotion: Planning and Strategies. Sage, London.

[7] Maurice B Mittelmark, 2017. Health Promotion. University of Bergen, Bergen, Norway.

[8] Department of Health In Indonesia. (2018, October). Health Promotion in Health Problem Areas. Retrieved from the Ministry of Health of the Republic of Indonesia: http://www.depkes.go.id/resources/download/promosi-k Kesehatan/panduan-promkes-dbk.pdf

[9] Efendi, F., \& Makhfudli. (2009). Community health nursing: theory and practice in nursing. Jakarta: Salemba Medika.

[10] Maulana, H. J. (2007). Health promotion. Jakarta: EGC

[11] Goldstein, S., \& Usdin, S. (2016). Children, Media and Health. In International Encyclopedia of Public Health (Second Edition, Vol. 1). https://doi.org/10.1016/B978-0-12-803678-5.00067-9 